\title{
Resenhas
}

\section{Uma Zona de Sombra: O rural de nossos dias ${ }^{1}$}

Márcia Motta ${ }^{2}$

MENDONÇA, Sonia Regina de. O Patronato Rural no Brasil Recente (1964-1993). Rio de Janeiro: Editora da UFRJ, 2010.

Uma zona de sombra da historiografia. É com estas palavras que a historiadora Sonia Mendonça apresenta o tema de sua trajetória acadêmica, mais uma vez registrada em livro. Ao perseguir as relações intraclasse dominante agrária, Mendonça discute em " $O$ Patronato Rural", como se estabelecem as relações e os fortes interesses dos grandes proprietários rurais no interior das agências estatais, entre os anos de 1964 a 1993.

O objeto de pesquisa por si só não é dos melhores, se entendemos uma obra a partir do registro de um passado festivo, cheio de glórias e comemorações.

\footnotetext{
${ }^{1}$ Resenha recebida e aprovada para publicação em julho de 2010.

${ }^{2}$ Doutora em Historia e Professora da Universidade Federal Fluminense
}

O tema é feio e seus efeitos são ainda piores, mas eles fazem parte do lado obscuro de nossa história, ainda tão presente e tão pouco estudado. Como fantasmas, seus efeitos perseguem alguns poucos historiadores, suficientemente preparados para desvendá-los por detrás dos véus.

$\mathrm{Na}$ contracorrente de uma história bonita, Mendonça dilacera nossas visões mais otimistas e demonstra que estamos ainda longe de um país mais generoso para com os seus. Ao perseguir e esquadrinhar os sentidos das "modernizações", a autora nos revela as estratégias utilizadas pelos terratenentes para chamar de nossos os seus interesses.

O livro exige leitura atenta, cuidadosa, já que a rigor o leitor mais desavi- 
sado, há de ter alguma dificuldade para acompanhar as principais ilações ali registradas. Para os mais interessados, asseguro: o esforço vale a pena. O próprio estilo da autora expressa uma resistência, contra as leituras prazerosas e superficiais de nossos dias. O leitor não estará lendo um resumo dos argumentos da imprensa diária, sempre pronta a falar sobre o que não sabe e a construir juízos de valor acerca de grupos sociais que desconhece. Também não há de encontrar ali um estilo poético, pois não há nada de poesia nos mecanismos de dominação/convencimento empregados pelos "nossos fazendeiros".

O capitulo primeiro é uma aula, dessas que - como dizíamos quando jovens - só mesmo a Sônia Mendonça para ministrar. Ao deslindar as propostas presentes no Estatuto da Terra do governo Castelo Branco, a autora nos oferece uma oportunidade ímpar de conhecer a fundo quais eram os distintos projetos políticos da Sociedade Nacional de Agricultura e da Sociedade Rural Brasileira - entidades patronais - na "luta travada entre elas pela condição de porta-vozes autorizados e legítimos das facções agrárias da classe dominante agrária". Mas se havia divisão, havia também união, cumplicidade; principalmente em relação aos projetos de reforma agrária dos setores de esquerda, na conjuntura que culminou com o Golpe de 64. É em oposição à mobilização camponesa e sua proposta de reforma que irão se insurgir as agremiações patronais, contra aquilo que consideram o mais grave dos crimes: $\mathrm{o}$ ataque à grande propriedade $\mathrm{e}$ ao direito de ser proprietário.

Não é preciso repetir aqui o que todos sabem e naturalizam. A partir do Golpe de 64, a grande propriedade rural é absolvida e consagra-se a ideia de que ela não deve ser discutida, questionada, mas estimulada. A concentração territorial não é mais um pecado; é, quanto muito, a expressão de nossa especificidade, num país que orgulhosamente chamamos de continental.

Não á toa, os anos de abertura política reinauguraram as tensões entre as entidades patronais, sempre dispostas a defender a política de modernização da agricultura com subsídios fiscais. Mas a abertura também implicou a renovação da esperança, a expectativa de um acerto de contas com o passado, expresso - por exemplo - na promulgação do Plano Nacional de Reforma Agrária do governo Sarney, cuja proposta, a princípio, visava atender às demandas sociais mais urgentes no campo, principalmente em relação aos conflitos fundiários. $\mathrm{O}$ fracasso da proposta expressou, mais uma vez, que a despeito das 
diferenças, as entidades patronais não estiveram dispostas a construir um consenso político a favor das mudanças.

O papel específico da Sociedade Nacional da Agricultura é o tema do capítulo dois. Nele, Mendonça analisa a revista $A$ Lavoura, corpus documental raras vezes utilizado pelos historiadores. Enquanto entidade de classe, a SNA defendeu suas propostas a partir de cinco eixos: a modernização da agricultura, a difusão do cooperativismo como instrumento de desenvolvimento agrícola, a necessidade de se empreender algum tipo de reforma agrária, a implementação de uma justiça agrária e o combate ao tabelamento de preços. Para além da excepcionalidade da entidade na defesa de algum tipo de reforma agrária e de justiça social (questões ausentes da pauta de outras entidades patronais) destaca-se também o apelo nos últimos anos em favor da causa ecológica, no esforço de consagrar-se como a legítima e histórica entidade preocupada com as questões ambientais.

O terceiro capítulo é dedicado à Sociedade Rural Brasileira, cujas visões de classe são expressas em outra revista A Rural, também pouquíssimo explorada por historiadores. Coerente com suas bases sociais, a entidade procuraria defender os interesses dos grandes cafeicultores, agropecuaristas e empre- sas agroindustriais. Em nome deste grupo, a SRB se poria radicalmente contra qualquer alteração da estrutura fundiária no país, na defesa de uma posição assentada na intocabilidade da propriedade territorial. Mas a entidade também criou uma dada concepção de reforma agrária que se consubstanciou na defesa de uma política agrícola e na construção de uma nova imagem do "moderno" produtor rural, "de cujos atributos a entidade ressaltava o uso da tecnologia/pesquisa de ponta".

Mas se a história do campo brasileiro tem a marca da complexidade, parece-nos óbvio que suas demandas e perspectivas não se resumem apenas a duas entidades de classe. Para além do dualismo e das disputas entre a SNA e a SRB, o quarto capítulo é dedicado ao estudo da Organização das Cooperativas Brasileiras, umas das mais jovens agremiações patronais que, após a abertura política, tornar-se-ia a grande força dirigente do patronato "agrário" nacional. $\mathrm{Na} \mathrm{OCB}$, o foco é o apelo ao cooperativismo, enquanto expressão maior da democracia e do igualitarismo. Entende-se assim que a reforma agrária defendida pela entidade está assentada na ideia do cooperativismo. Seus dirigentes se veem como os portavozes do que há de mais moderno: o agronegócio, modernizando a agricul- 
tura brasileira em bases empresariais e internacionalizadas. A atuação da entidade é ainda o exemplo emblemático das estratégias de construção de hegemonia e de representação política no interior do Estado Brasileiro.

O coroamento desta hegemonia expressa na consolidação do papel e importância do agronegócio - é exemplificado pela criação da Associação Brasileira de Agribusiness, objeto do último capítulo. Em nome do novo o agronegócio - e da necessidade de encontrar novos canais de representação política, a ABAG, como é comumente chamada, constitui-se na face mais obscura do poder dos empresários rurais, não apenas como uma entidade patronal de defesa de seus interesses de classe, mas como uma agremiação de empresas. A "responsabilidade social dos empresários do agronegócio com a sustentação alimentar de uma comunidade internacional altamente 'globalizada' seria o grande argumento de sua legitimação e da produção do consenso em âmbito nacional". Na construção deste discurso e na falácia do consenso, a sociedade brasileira condena - sem ao menos se dar a conhecer - a pequena produção familiar que, mais uma vez, é refém de valores sociais que lhe são impostos de fora: atrasada, antiprodutiva, sem função.
Há, em suma, um novo projeto para a agricultura brasileira, vendido em prosas e versos nas campanhas publicitárias, nas propostas do governo, nas telenovelas, nos jornais. Tal projeto - o agribusiness - dificulta o nosso olhar sobre os problemas e mazelas do campo brasileiro e deslegitima e condena ao esquecimento a trajetória e luta dos pequenos agricultores deste país, responsáveis - eles sim - por parte ainda importante da produção de alimentos do Brasil. Eu conto nos dedos quantos historiadores estão cientes desta elementar informação... 